\title{
Knowledge Management: A Case Study on Employees Knowledge-Oriented Behaviour in the Electricity Distribution Company
}

\author{
Raja Danial Raja Ismail ${ }^{1} \&$ Zunaidah Sulong $^{1}$ \\ ${ }^{1}$ Faculty of Business Management and Accountancy, Universiti Sultan Zainal Abidin, Terengganu, Malaysia \\ Correspondence: Raja Danial Raja Ismail, Faculty of Business Management and Accountancy, Universiti Sultan \\ Zainal Abidin, Terengganu, Malaysia. Tel: 60-9-668-8220. E-mail: rajadanial@unisza.edu.my
}

Received: March 12, 2013 Accepted: April 16, 2013 Online Published: June 1, 2013

doi:10.5539/ass.v9n7p218 URL: http://dx.doi.org/10.5539/ass.v9n7p218

\begin{abstract}
The paper investigates the views of Managers and Senior Managers in an electricity distribution company in Malaysia with respect to human elements of Knowledge Management (KM). Based on three Knowledge Management tasks, i.e. Knowledge Application, Knowledge Distribution, and Knowledge Cultivation, the respondents collectively perceive that KM tasks are important to the company. The existing KM tasks are positively correlated with the ease of occurrence of KM activities that support those tasks. The behaviour is positively correlated with the ease of occurrence of KM activity groups of Culture, Embeddedness, Spontaneity, Subjectivity, and Transferability. Knowledge-oriented behaviour is positively correlated with organization performance, and there are positive correlations between KM tasks and knowledge culture.
\end{abstract}

Keywords: knowledge management, knowledge-oriented behaviour, knowledge-enabled, organization performance, Malaysia

\section{Introduction}

In the present day organizations, the basic building blocks are diverse. Many companies that want to strengthen their long-term survival turn towards basic building blocks that characterize many of the successful organizations. These building blocks range from the deterministic models of optimization input and output to the more social and psychological factors of their employees. The latter include management practices that build high commitment of employees, excellent employees performance, high levels of skills, high motivation, greater loyalty, etc., all of which are geared towards one objective, namely an organization that produces good results.

Knowledge Management (hereafter, KM) is defined as the process of managing the cycle of capturing knowledge from organizational activities and learning from that knowledge about scope for improved organizational effectiveness through changes to behaviour and organizational activity (Costello, 1996). Many organizations do not have full grasp of KM, especially when it is noted that KM involves more than information technology (IT). If more than a third of total time and money of a KM project is on technology, it is considered as IT project and not knowledge project (Davenport \& Prusak, 1998). IT accounts only about a third of Knowledge Management, the other two-thirds are about people and their ideas. Tiwana (2000) (Note1). admits that Knowledge management is 35 percent technology and the rest (65 percent) are people and processes. Gamble and Blackwell (2001) also noted that "Knowledge Management is probably 80 to 85 percent about people and their ideas. Technology is just an enabler" (Gamble \& Blackwell, 2001) (Note 2). Technology facilitates the capturing, documenting, storing, searching, retrieving and distributing the knowledge.

Large organization is made up of groups of people of various specialization and mind-sets. One of the fears they have is that once the KM movement sets-in, the organization structure that normally enables tasks to be done smoothly and efficiently may be changed with uncertain outcome, employees' behaviour may change (for instance, they will be more absorbed in exchanging knowledge and ideas rather than doing actual work), and the organization performance declines.

Notwithstanding, the emergence of knowledge workers and the more important roles they play and increasing responsibility they assume must be acknowledged by an organization. The more knowledgeable the employees are, the more challenges and risks they are prepared to take. In some companies the need for a Knowledge 
Management initiative comes from the top. For example, at some Japanese companies, the CEOs themselves assume the responsibility to articulate the company's "conceptual umbrella", i.e. grand concepts in highly universal and abstract terms identifying the common features linking seemingly disparate activities or businesses into a coherent whole (Nonaka, 1991).

In knowledge management, human factors are very important. This is because tacit knowledge (Note 3 ) resides in human mind. Also, new knowledge comes, in large part, from experiences residing in the human mind. In an organization, new knowledge may also be an extrapolation of existing knowledge, or a totally new knowledge. According to Drucker (1993) these, respectively, are improvement and innovation.

Managing knowledge involves identifying existing knowledge within the organization, sharing the knowledge, applying the knowledge, and creating new knowledge from existing knowledge, then share and use it. The process is cyclical but knowledge store is increased. Organizations need to develop the knowledge and capabilities of new and existing employees. Often, new employees work closely with experienced employees (coaching) in order for the explicit and tacit knowledge of the experienced employees be transferred to the new employees. This is one way of ensuring that the knowledge within the organization is not lost when a specialist or knowledgeable employees leave the organization (through retirement or resignation). Managing knowledge also includes training with experts to impart new technologies and knowledge to the employees, and to follow the best practices of similar organizations.

Knowledge-enabled organization has certain key characteristics that focus on capabilities and enablers that produce results. Among the characteristics are team-based collaborative work, cross-functional work, localized decision making, and recognition of the need to share to achieve set objectives. Information technology is used when it is required. What are important about the technology is how it is used, what it is used for, and why it is used. Satisfying senior management by installing range of information services can reduce the pressure to adopt an overall perspective of knowledge management (Gamble \& Blackwell, 2001). Technology does not change actual behaviour, and access to knowledge sources does not in itself add value, unless people spend time in thinking and deliberating over the knowledge, and consensus is reached (among the members of the organization or members of a team) as to the usefulness and applicability of the knowledge within the job context. It is the people that matters: their group culture, their mind set, their relationships, their ignorance, their insights, their approach to problem solving, their perception of the jobs, their capacity to learn, inability to use what they learn, and their performance (Pfeffer \& Sutton, 2000). Many studies point to the direction of vital connection between knowledge-oriented behaviour and the employee performance, and hence organization performance (for example, Davenport \& Prusak, 2000; Kluge, 2001; Nonaka \& Takeuchi, 1995; Brooking, 1999). This paper focuses on essential knowledge-oriented behaviours.

This paper investigates the elements of human aspects of the KM in an electricity distribution company in Malaysia, the largest subsidiary of an electric utility company called Tenaga Nasional Berhad, or TNB (the name of the electric distribution subsidiary is TNB Distribution Sdn. Bhd., or TNBD). Employees in TNBD work in teams to perform their jobs. The jobs are basically technical in nature: to install new electricity supply to customers, to repair electric substations (in cases of breakdown), to repair underground or overhead cables damages, to conduct routine maintenance on switchgears, cables, and substations, to lay new cables to newly developed housing estates, commercial centres or industrial areas, to extend the coverage area of the National Grid, etc.

TNBD is the largest wholly owned subsidiaries of TNB. Its total numbers of employees are over 14,000 (Note 4), with over 1,000 electrical engineers, and over 8,000 technical workers (Technical Assistants, Supervisors, and Technicians). It supplies the electricity to about 5.5 million customers distributed among five main sectors: domestic, commercial, industrial, public lighting, and mining.

The engineers within TNBD need to interact with one another. They exchange ideas how to best manage their projects, their teams, and the customers. They must perform to achieve the KPIs (Key Performance Indicators) (Note 5) agreed by TNBD management. Informal communications, informal discussions, meetings, interacting with material suppliers, with external experts, with peers and colleagues are a norm within TNBD. They need to socialize, interact and exchange knowledge and best practices among themselves so they can achieve the set KPI's.

TNBD does not have a dedicated computerised system that specifically made to maximize the benefits of Knowledge Management (Note 6). But the employees' daily activities do translate into knowledge management activities, and supportive knowledge culture and knowledge-oriented human behaviour. 
The purpose of this paper is to investigate the effectiveness of the practices within the company from the perspective of human related aspects of Knowledge Management. It addresses the essential human knowledge-oriented activities and knowledge management tasks-their importance, the current state of the activities and tasks, and the ease of occurrence of the activities and tasks in TNBD, and the implications of the knowledge-oriented activities and knowledge tasks to behaviours employees' and the organization performance.

\section{Literature Review}

In many cases IT can facilitate knowledge workers, but technology is not enough. Knowledge and the process of managing it existed long ago in the production of goods, but then there was no KM technology. Technology can enable individuals to carry out several KM processes that were harder to do before. However, the motivations to share, create, and exploit knowledge rest in people and require different analysis and levers than technology (Garavelli, 2003).

Bennett and Gabriel (1999), in their study of large marketing companies, rejected the hypothesis that less bureaucratic organization tend to possess extensive KM systems. Their study focused on both aspects of knowledge management, namely KM methods (electronic discussion forums, video-conferencing, etc.), and the organizational and human factors (ability to cope with change, innovative, teamwork, bureaucracy and centralization, reluctance to share knowledge, and accessibility to knowledge and expertise either residing in databases or in the minds of employees). Their study demonstrates that KM has both the elements of technology and human and organizational aspects.

\subsection{Knowledge Work and Knowledge Workers}

Knowledge work is often referred to work that is in contrast to manual work. Procedural knowledge, i.e. knowledge how to do things are necessary in knowledge work. Drucker (1992) states that:

"The 'knowledge employee' may well need a machine, whether it be a computer, an ultrasound analyzer, or a telescope. But the machine will not tell the knowledge worker what to do, let alone how to do it. And without this knowledge, which belongs to the employee, the machine is unproductive." (Drucker, 1992).

Equally important is the knowledge of how to make the work more efficient, more productive, with high quality workmanship, at lowest cost, while at the same time satisfying the needs of customers. Decentralization, empowerment, autonomous work groups, communities of practices, team-work, etc. are devices that organizations can use in order to be more productive, more efficient, giving employees' greater satisfaction at work, etc.

All work requires knowledge of some extent, and all work is social and cooperative in some respect (Iivari \& Linger, 1999), and due to increase complexities of problems, work tends to be increasingly collaborative. In turn, the socialization creates new knowledge. Iivari and Linger (1999) uses the term "body of knowledge" to describe knowledge work. The "body of knowledge" is knowledge about relevant phenomena associated with knowledge work. It comprises of facts, rules, techniques, case histories (cases), stories, theories, hypothesis, philosophies, metaphors, etc. (Iivari \& Linger, 1999). Understanding and application of the "body of knowledge" always require tacit knowledge and historically developed expertise (a combination of knowledge and skill) embedded in the organization. Uses of the "body of knowledge" often emerge spontaneously within groups and members of the group use the "body of knowledge" to perform their tasks.

Knowledge work can be classified as: craft-like knowledge work, routine knowledge work, professional knowledge work, and creative knowledge work. The "body of knowledge" for professional knowledge work (involves adaptation, application) includes theories, approaches, and strategies. For routine knowledge work (for instance, a routine machine operation), it includes techniques and facts applicable to the task. For craft knowledge work it is skills that are important which are learned through practical experiences and apprenticeship There are no clear rules and techniques in craft knowledge work, but it may have historical cases or patterns as part of its "body of knowledge". For creative knowledge work (involves imagination, improvisation, etc.), its body of knowledge includes philosophies, visions and metaphors. A creative process always has "mystical elements" that are hard to capture. In each classification of knowledge work, situations or contexts are part of "body of knowledge". In engineering work, professional knowledge work is the most relevant, but the other three classifications of knowledge work also present. Learning can improve the organization of the "body of knowledge" such as better understanding of the relationship between facts and theories (Iivari \& Linger, 1999)

\subsection{Human Behaviour}

The behaviour refers to how people acquire knowledge, use the knowledge and transfer the knowledge in their 
daily work. Their goals are to get results and to achieve objectives they set out to accomplish. The means of getting the results can be different from organization that value knowledge activities than those that are not. Furthermore, the performance of the organization can differ between the organization that practice knowledge-oriented activities and those that do not.

Knowledge Management has the human and technology aspects to it. If the organization does not support knowledge sharing practices, technology investment will not help. Information Technology is tactically positioned on the explicit side of tacit-explicit knowledge continuum. It will not replace the value of, and the need for, face-to-face interaction. Face to face interactions, such as the practices of apprenticeships, mentoring, coaching and communities of practice, are the most efficient way to convey tacit knowledge throughout the organization (Frappaolo, 2002)

KM activities impact people - people show more affinity to work and exchange ideas with team members, more productive in work, more motivation to learn more about the jobs, like to expose themselves to more learning about situations of the jobs, to work more with suppliers if this is a success factor in their jobs, look forward to seminars, conferences, and congregation of like minds and peers. People who are committed to knowledge would view every occasion, every remark, and every interaction, as valuable. Knowledge breeds more knowledge, i.e. new knowledge is built from previous knowledge. According to Drucker (1992, 1993), knowledge is created through continuous self-improvement as well as through exploitation of existing knowledge (Note 7) and innovation.

Individuals interact with one another and group learning is achieved. Through their social interaction, each person's "self-concept" (of values, norms, and behaviours) interacts with one another (by following their individual "script") to form the group's unique "schema". Individual has a cognitive infrastructure that is inherently social and leads each individual to try to achieve "cognitive congruence" in the interactions (Merali, 2001). Existing group's cognitive equilibrium can be disturbed by new problems that require new solutions. For instance some organizations gain new knowledge through client relationships (Sivula et al., 2001). The drive to re-establish cognitive congruence must be guided (managed) with clear desired new values and norms from the group. According to Sanchez (2001), learning and knowledge accumulation should progressively moves upwards from individual learning cycle and group interactions, to group learning cycle, and to group interaction with the organization. For the latter, top management plays an important role to facilitate the exchanges of knowledge and information between groups, i.e. top management is in constant communication with the various groups (Raub, 2001).

Most human work is carried out in teams, and appropriate type of team is required for knowledge work (Drucker, 1993). Knowledge demands continuous learning because it is constantly changing. Effective knowledge work teams must build continuous learning into the job and the organization (Drucker, 1993). Traditionally, works on new products go through each function of design, engineering, manufacturing, and marketing. Work is done in one function and passed to the next. This is also a form of teamwork.

\subsection{Knowledge Management}

O'Dell and Grayson (1998) believed that in a few years knowledge management would become part of the organization, like just-in-time management, cycle time reduction, and total quality management. Broadly, knowledge has two aspects: explicit and tacit (Nonaka 1991). Explicit knowledge is formal, unambiguous and systematic. Tacit knowledge is knowledge that is intuitive and ambiguous. Tacit knowledge has roots in individuals experience and unlike explicit knowledge, it is difficult to process, transfer and share. Other forms of knowledge categorization are possible, for example: static knowledge; dynamic knowledge; declarative knowledge (knowledge of facts); procedural knowledge (knowledge of how to do things); knowledge that is abstract (in that it may apply to many situations); knowledge that is specific (in that it applies only to one situation) (Gamble \& Blackwell, 2001). McKinsey \& Company, Inc. categorizes knowledge assets into: 1) "Know What-Explicit" (labeled as "Information", such as facts, theories, or people to contact); 2) "Know How-Explicit" (labeled as "Procedures", such as policies, standard processes, expert systems, etc.); 3) "Know What-Tacit" (labeled as "Beliefs", such as values, intuition, and judgment; and 4) "Know How-Tacit" (labeled as "Skills", such as personal expertise and team skills) (McKinsey \& Company, Inc., 2001) (Note 8). Explicit attribute means structured and codified, and tacit attribute means unstructured and un-codified.

Knowledge management is a conscious effort by the organization to enable to create and disseminate knowledge, using knowledge to produce new knowledge, delivered new products, improve performance, to increase productivity, market leadership, to compete better, and to produce better results for the organization. Knowledge management is also being used by organization to cope with the loss of knowledge as employees leave the 
organization (Hildreth, 2000). As commercial organizations face up to modern commercial pressures and react with measures such as downsizing and outsourcing they have come to realize that they have lost a lot of knowledge as people have left. Knowledge management in the form of socialization through communities of practice is one way to deal with the problem.

When knowledge management is implemented in an organization, there will be a shift from a power-based organization to a responsibility-based organization (Drucker, 1993). The knowledge-based organization must build responsibility from within. Specialization in knowledge (concentration), teamwork, defined performance and objectives create responsible workers. They feel motivated and recognized, and eager to further their knowledge, and therefore being responsible on what they do and achieved. Only limited power remain in the organization, power for hiring or for taking disciplinary action on employees, setting criteria for further education, setting working hours, assigning jobs and tasks to individuals, opening or closing a unit/department.

\section{Methodology}

The paper utilised questionnaire developed to address the human aspects of Knowledge Management. Organization should have certain practices in order to facilitate the processes of knowledge creation, distribution and application. In this paper, these practices are called Knowledge Management activities, or simply knowledge activities. There are ten questions in the questionnaire. A set of five questions is devoted to Knowledge Management tasks; each question has three items: knowledge creation, knowledge distribution, and knowledge application. Another set of five questions is devoted to Knowledge Management activities; each question has 20 items. They are by no means an exhaustive list of knowledge-related activities of TNBD, but they are important in the context of Knowledge Management (KM), especially the human aspects of KM. The 20 items are categorized into Culture and six knowledge characteristics: Embeddedness, Perishability, Self-reinforcement, Spontaneity, Subjectivity, and Transferability (Kluge et al., 2001).

Definitions of the characteristics are:

Subjectivity: The interpretation of knowledge is heavily dependent on individual past knowledge, experiences, and the context to which it will be put to use.

Transferability: Knowledge can be extracted or transferred from one context or application and applied in another.

Embeddedness: Initially knowledge is often tacit and not codified. Some cannot be codified to the exactness required.

Self-reinforcement: Unlike asset, which is stable or reduces in value when shared, knowledge value increases when it is shared among people.

Perishability: The value of knowledge diminishes over time, or it can be instantaneously outdated.

Spontaneity: Knowledge is often generated randomly (unpredictably) and the generation cannot be systematically planned.

The data is gathered by distributing the questionnaire to the respondents, and collected a few days later. Some respondents answered the questionnaire while the researcher waited for the questionnaire to be completed. For respondents that are far away the questionnaire (and the reply) is sent through e-mail. Then follow-up phone calls were made to the individuals the questionnaires were sent.

The analyses are inferential type, based on hypothesis testing. Simple and multiple regression, and correlation analyses were performed on the collected data using SPSS software. Some analyses were done on the activities and some were done on the culture and six knowledge characteristics categories (by aggregating and averaging the activities scores in each category). The output tables list the activities by these categories.

The paper will consider five main hypotheses to be tested, which are;

Hypothesis $1\left(\mathrm{H}_{1}\right)$ : Human behaviour is positively correlated with the perceived importance of knowledge activities.

Hypothesis $2\left(\mathrm{H}_{2}\right)$ : Human behaviour is positively correlated with the ease with which the knowledge activities can occur.

Hypothesis $3\left(\mathrm{H}_{3}\right)$ : Grouped into knowledge culture and knowledge characteristics, the perceived importance of knowledge-oriented activities accounts for more of the variance of human behaviour compared to ease of occurrence.

Hypothesis $4\left(\mathrm{H}_{4}\right)$ : The human behaviour in relation to knowledge management activities is positively correlated 
with the organization performance.

Hypothesis $5\left(\mathrm{H}_{5}\right)$ : There is a positive correlation between each of existing knowledge management tasks and each element of the existing knowledge culture.

\section{Analysis of Findings}

The importance of KM tasks, their existence within the company, the ease in which knowledge tasks can occur, and their relation to organization performance are in Table 1.

Table 1. The mean values and standard deviations of importance, existing state, and ease of occurrence of KM tasks

\begin{tabular}{|c|c|c|c|c|c|c|c|c|}
\hline KM Tasks & $\begin{array}{l}\text { Perceived } \\
\text { Importance }\end{array}$ & SD & $\begin{array}{l}\text { Existing } \\
\text { Situation }\end{array}$ & SD & $\begin{array}{l}\text { Ease } \\
\text { Level }\end{array}$ & SD & $\begin{array}{l}\text { Organization } \\
\text { Performance }\end{array}$ & SD \\
\hline $\begin{array}{l}\text { Knowledge } \\
\text { Application }\end{array}$ & 3.95 & $\begin{array}{c}0.91 \\
(\mathrm{~N}=75)\end{array}$ & 3.88 & $\begin{array}{c}0.82 \\
(\mathrm{~N}=75)\end{array}$ & 3.61 & $\begin{array}{c}0.66 \\
(\mathrm{~N}=75)\end{array}$ & 3.61 & $\begin{array}{c}0.87 \\
(\mathrm{~N}=75)\end{array}$ \\
\hline $\begin{array}{l}\text { Knowledge } \\
\text { Distribution }\end{array}$ & 4.05 & $\begin{array}{c}0.97 \\
(\mathrm{~N}=75)\end{array}$ & 3.09 & $\begin{array}{c}0.82 \\
(\mathrm{~N}=75)\end{array}$ & 3.15 & $\begin{array}{c}0.77 \\
(\mathrm{~N}=75)\end{array}$ & 4.52 & $\begin{array}{c}0.55 \\
(\mathrm{~N}=75)\end{array}$ \\
\hline $\begin{array}{l}\text { Knowledge } \\
\text { Cultivation }\end{array}$ & 4.52 & $\begin{array}{c}1.00 \\
(\mathrm{~N}=75)\end{array}$ & 3.25 & $\begin{array}{c}0.68 \\
(\mathrm{~N}=75)\end{array}$ & 2.85 & $\begin{array}{c}0.82 \\
(\mathrm{~N}=75)\end{array}$ & 4.44 & $\begin{array}{c}0.70 \\
(\mathrm{~N}=75)\end{array}$ \\
\hline
\end{tabular}

All the KM tasks (knowledge application, knowledge distribution, and knowledge cultivation) are perceived as importance to the organization. Knowledge cultivation is perceived as the most important, followed by knowledge distribution and knowledge application. The managers view that the activities of knowledge distribution (sharing) within TNBD is perceived to be most related to the organization performance, followed by knowledge cultivation and knowledge application.

The correlation and regression analyses are used to test the five hypotheses.

To test $\mathrm{H}_{1}$, Pearson's product moment correlation coefficients are computed between knowledge-related human behaviour and the perceived importance of knowledge management activities. The results are presented in Table 2. Fourteen (14) items have positive correlations significant at 0.05 or below, and six items are not statistically significantly correlated. It is concluded that that data partially support the hypothesis. 
Table 2. Correlation between existing state of knowledge activities and behaviour related to the activities

\begin{tabular}{|c|c|c|c|}
\hline No & Knowledge Activities & Pearson Correlation & Sig. (1-tailed) \\
\hline & Culture & & \\
\hline 1 & Recognize and praise for creative ideas & $0.212 *$ & $0.034(\mathrm{~N}=75)$ \\
\hline 2 & Support by top management & 0.172 & $0.070(\mathrm{~N}=75)$ \\
\hline 3 & $\begin{array}{l}\text { Employees actively involved in improvement } \\
\text { decisions. }\end{array}$ & $0.225^{*}$ & $0.027(\mathrm{~N}=74)$ \\
\hline 4 & $\begin{array}{l}\text { Increase emphasis on human aspects in the } \\
\text { performance appraisals }\end{array}$ & 0.183 & $0.058(\mathrm{~N}=75)$ \\
\hline & Embeddedness & & \\
\hline 5 & $\begin{array}{l}\text { Members from different teams interacting and } \\
\text { exchanging knowledge }\end{array}$ & $0.282^{* *}$ & $0.007(\mathrm{~N}=75)$ \\
\hline 6 & Working in teams & 0.102 & $0.195(\mathrm{~N}=74)$ \\
\hline 7 & $\begin{array}{l}\text { Members from same team interacting and } \\
\text { exchanging knowledge }\end{array}$ & $0.244 *$ & $0.018(\mathrm{~N}=74)$ \\
\hline 8 & $\begin{array}{l}\text { Work closely with external partners } \\
\text { Perishability }\end{array}$ & 0.136 & $0.121(\mathrm{~N}=75)$ \\
\hline 9 & Company-wide process standards & 0.121 & $0.150(\mathrm{~N}=75)$ \\
\hline 10 & $\begin{array}{l}\text { Systematic retention and updating of process } \\
\text { experiences. } \\
\text { Self-reinforcement }\end{array}$ & $0.255^{* *}$ & $0.013(\mathrm{~N}=75)$ \\
\hline 11 & Regular training with internal and external experts. & $0.233^{*}$ & $0.022(\mathrm{~N}=75)$ \\
\hline 12 & $\begin{array}{l}\text { Access to various internal databases. } \\
\text { Spontaneity }\end{array}$ & $0.188^{*}$ & $0.053(\mathrm{~N}=75)$ \\
\hline 13 & Informal groups & $0.444^{* *}$ & $0.000(\mathrm{~N}=75)$ \\
\hline 14 & $\begin{array}{l}\text { Creative and innovative } \\
\text { Subjectivity }\end{array}$ & 0.112 & $0.168(\mathrm{~N}=75)$ \\
\hline 15 & $\begin{array}{l}\text { Frequent informal top-down and bottom-up } \\
\text { communications. }\end{array}$ & $0.376^{* *}$ & $0.000(\mathrm{~N}=75)$ \\
\hline 16 & Cross-functional teams. & $0.402 * *$ & $0.000(\mathrm{~N}=74)$ \\
\hline 17 & $\begin{array}{l}\text { Common understanding and interpretation of } \\
\text { knowledge } \\
\text { Transferability }\end{array}$ & $0.194 *$ & $0.047(\mathrm{~N}=75)$ \\
\hline 18 & Working closely with other related departments/units & $0.265^{* *}$ & $0.011(\mathrm{~N}=75)$ \\
\hline 19 & Internal benchmarking & $0.451^{* *}$ & $0.000(\mathrm{~N}=75)$ \\
\hline 20 & Adapt knowledge from other applications & $0.244^{*}$ & $0.019(\mathrm{~N}=73)$ \\
\hline
\end{tabular}

To test $\mathrm{H}_{2}$, Pearson's product moment correlation coefficients are computed between human behaviour and the current state of knowledge management activities. The correlations are computed for each of the twenty knowledge activities. The results are presented in Table 3. Seven items have positive correlations significant at 0.05 or below, the rest are not statistically significantly correlated. It is concluded that that data partially support the hypothesis. 
Table 3. Correlation between ease of occurrence of knowledge activities and behaviour related to the activities

\begin{tabular}{|c|c|c|c|}
\hline No. & Knowledge Activities & $\begin{array}{l}\text { Pearson } \\
\text { Correlation }\end{array}$ & $\begin{array}{l}\text { Sig. } \\
\text { (1-tailed) }\end{array}$ \\
\hline & Culture & & \\
\hline 1 & Recognize and praise for creative ideas & $0.221 *$ & $0.029(\mathrm{~N}=74)$ \\
\hline 2 & Support by top management & 0.092 & $0.218(\mathrm{~N}=74)$ \\
\hline 3 & Employees actively involved in improvement decisions. & 0.125 & $0.147(\mathrm{~N}=73)$ \\
\hline 4 & $\begin{array}{l}\text { Increase emphasis on human aspects in the performance appraisals } \\
\text { Embeddedness }\end{array}$ & 0.038 & $0.374(\mathrm{~N}=75)$ \\
\hline 5 & $\begin{array}{l}\text { Members from different teams interacting and exchanging } \\
\text { knowledge }\end{array}$ & 0.176 & $0.066(\mathrm{~N}=75)$ \\
\hline 6 & Working in teams & $0.242 *$ & $0.019(\mathrm{~N}=74)$ \\
\hline 7 & Members from same team interacting and exchanging knowledge & 0.097 & $0.206(\mathrm{~N}=74)$ \\
\hline 8 & $\begin{array}{l}\text { Work closely with external partners } \\
\text { Perishability }\end{array}$ & $0.203 *$ & $0.041(\mathrm{~N}=75)$ \\
\hline 9 & Company-wide process standards & -0.045 & $0.350(\mathrm{~N}=75)$ \\
\hline 10 & $\begin{array}{l}\text { Systematic retention and updating of process experiences. } \\
\text { Self-reinforcement }\end{array}$ & -0.005 & $0.484(\mathrm{~N}=75)$ \\
\hline 11 & Regular training with internal and external experts. & -0.011 & $0.463(\mathrm{~N}=75)$ \\
\hline 12 & $\begin{array}{l}\text { Access to various internal databases. } \\
\text { Spontaneity }\end{array}$ & -0.049 & $0.339(\mathrm{~N}=75)$ \\
\hline 13 & Informal groups & 0.010 & $0.465(\mathrm{~N}=75)$ \\
\hline 14 & $\begin{array}{l}\text { Creative and innovative } \\
\text { Subjectivity }\end{array}$ & $0.209 *$ & $0.036(\mathrm{~N}=75)$ \\
\hline 15 & Frequent informal top-down and bottom-up communications. & $0.252 *$ & $0.016(\mathrm{~N}=73)$ \\
\hline 16 & Cross-functional teams. & $0.238^{*}$ & $0.020(\mathrm{~N}=75)$ \\
\hline 17 & $\begin{array}{l}\text { Common understanding and interpretation of knowledge } \\
\text { Transferability }\end{array}$ & 0.070 & $0.276(\mathrm{~N}=75)$ \\
\hline 18 & Working closely with other related departments/units & 0.111 & $0.173(\mathrm{~N}=74)$ \\
\hline 19 & Internal benchmarking & 0.071 & $0.277(\mathrm{~N}=73)$ \\
\hline 20 & Adapt knowledge from other applications & $0.271^{* *}$ & $0.010(\mathrm{~N}=74)$ \\
\hline
\end{tabular}

**Correlation is significant at the 0.01 level (1-tailed)

*Correlation is significant at the 0.05 level (1-tailed)

To test $\mathrm{H}_{3}$, a multiple regression model is computed, as follows:

BEHAV $=\beta_{0}+\beta_{1}($ ACTIVITY_IMPORTANCE $)+\beta_{2}($ ACTIVITY_EASE $)$

Where:

BEHAV is "behaviour dimension" of knowledge activities grouped according to underlying knowledge characteristics/culture.

ACTIVITY_IMPORTANCE is "perceived importance" of knowledge activities grouped according to underlying knowledge characteristics/culture.

ACTIVITY_EASE is the "ease of occurrence" of knowledge activities grouped according to underlying knowledge characteristics/culture. 
The results are in Table 4. The F-statistic shows that the regression model is statistically significant at 0.05 or better for five of the seven items, i.e. "culture" and the characteristics "self-reinforcement", "spontaneity", "subjectivity", and "transferability". For "Embeddedness" the F-statistic is only significant at level of 0.063 , and for "perishability" at 0.057 level of significant. The standardized beta coefficients for ACTIVITY IMPORTANCE are significant at 0.001 for four characteristics, and at 0.05 for one characteristic. The standardized beta coefficient for ACTIVITY_EASE is significant only for "Subjectivity" and its Partial- ${ }^{2}$ is bigger for ACTIVITY_IMPORTANCE compared to ACTIVITY_EASE. It is concluded that the data partially support the hypothesis.

From collinearity/multicollinearity tests, it is concluded that multicollinearity in the model is not a serious problem.

Table 4. Regression that explains the relationship of behaviour, perceived importance, and ease of occurrence of knowledge-oriented activities, grouped into knowledge culture and knowledge characteristics

\begin{tabular}{lllllll}
\hline & Model fit & & \multicolumn{2}{l}{ Perceived Importance } & \multicolumn{2}{l}{ Ease of Occurrence } \\
\hline Knowledge Characteristic & F-value & Adj. $\mathrm{R}^{2}$ & Std. $\beta_{1}$ & Partial R & Std. $\beta_{2}$ & Partial R $^{2}$ \\
Culture & $3.506^{*}$ & 0.063 & 0.158 & 0.024 & 0.208 & 0.041 \\
& $(0.035)$ & $(0.089)$ & $(0.188)$ & & $(0.084)$ & \\
Embedded-ness & 2.879 & 0.048 & 0.168 & 0.028 & 0.176 & 0.030 \\
& $(0.063)$ & $(0.074)$ & $(0.156)$ & & $(0.138)$ & \\
Perishability & 2,978 & 0.051 & $0.278^{*}$ & 0.076 & -0.028 & 0.001 \\
& $(0.057)$ & $(0.076)$ & $(0.017)$ & & $(0.809)$ & \\
Self-reinforcement & $4.278^{*}$ & 0.081 & $0.327^{* *}$ & 0.105 & -0.079 & 0.007 \\
& $(0.018)$ & $(0.106)$ & $(0.005)$ & & $(0.482)$ & \\
Spontaneity & $5.320^{* *}$ & 0.105 & $0.304^{* *}$ & 0.092 & 0.137 & 0.020 \\
Subjectivity & $(0.007)$ & $(0.129)$ & $(0.009)$ & & $(0.228)$ & \\
Transferability & $11.949^{* *}$ & 0.228 & $0.403^{* *}$ & 0.171 & $0.219^{*}$ & 0.057 \\
& $(0.000)$ & $(0.249)$ & $(0.000)$ & & $(0.040)$ & \\
& $10.235^{* *}$ & 0.200 & $0.434^{* *}$ & 0.175 & 0.085 & 0.008 \\
\hline
\end{tabular}

* Significant at 0.05 level.

** Significant at 0.01 level.

F-test sig. for F-statistic and t-test sig. for beta coefficients are shown in parentheses.

For $\mathrm{R}^{2}$ column, the value in parenthesis is the unadjusted $-\mathrm{R}^{2}$.

To test $\mathrm{H}_{4}$, Pearson's correlation coefficients between employees' behaviour and the organization performance are computed for each of the twenty knowledge management activities. The results of the correlation coefficients are presented in Table 5. Five items have coefficients above 0.5 (moderate correlations). Nine items have coefficients between 0.4 and 0.5 (moderate correlations). Four items have coefficients between 0.3 and 0.4 (moderate correlations). Only one item has coefficients less than 0.3 (weak correlation). All these items are significant at $<0.01$ level, i.e. the probability that behaviour and organization performance are not correlated with respect to knowledge management activities is less than $1 \%$. Only one item has insignificant correlation (item 8 ). It is concluded that the data support the hypothesis, i.e. in relation to knowledge management activities, human (employees) behaviour and organization performance are positively correlated. 
Table 5. Correlations between human behaviour and performance related to knowledge management activities

\begin{tabular}{|c|c|c|c|c|}
\hline & Item & Pearson Correlation & Sig. (1-tailed) & $\mathrm{N}$ \\
\hline & Culture & & & \\
\hline 1 & Recognize and praise for creative ideas & $0.506^{* *}$ & 0.000 & 75 \\
\hline 2 & Support by top management & $0.247^{*}$ & 0.016 & 75 \\
\hline 3 & Employees actively involved in improvement & & & \\
\hline & decisions. & $0.407 * *$ & 0.000 & 74 \\
\hline 4 & $\begin{array}{l}\text { Increase emphasis on human aspects in the } \\
\text { performance appraisals }\end{array}$ & $0.446^{* *}$ & 0.000 & 74 \\
\hline & Embeddedness & & & \\
\hline 5 & $\begin{array}{l}\text { Members of different teams interacting and } \\
\text { exchanging knowledge }\end{array}$ & $0.426^{* *}$ & 0.000 & 74 \\
\hline 6 & Working in teams & $0.420 * *$ & 0.000 & 74 \\
\hline 7 & $\begin{array}{l}\text { Members of same team interacting and } \\
\text { exchanging knowledge }\end{array}$ & $0.303 * *$ & 0.005 & 72 \\
\hline 8 & $\begin{array}{l}\text { Work closely with external partners } \\
\text { Perishability }\end{array}$ & $0.521 * *$ & 0.000 & 73 \\
\hline 9 & Company-wide process standards & $0.522 * *$ & 0.000 & 74 \\
\hline 10 & $\begin{array}{l}\text { Systematic retention and updating of process } \\
\text { experiences. } \\
\text { Self-reinforcement }\end{array}$ & $0.425^{* *}$ & 0.000 & 74 \\
\hline 11 & $\begin{array}{l}\text { Regular training with internal and external } \\
\text { experts. }\end{array}$ & $0.585^{* *}$ & 0.000 & 73 \\
\hline 12 & $\begin{array}{l}\text { Access to various internal databases. } \\
\text { Spontaneity }\end{array}$ & $0.429 * *$ & 0.000 & 73 \\
\hline 13 & Informal groups & $0.488^{* *}$ & 0.000 & 73 \\
\hline 14 & $\begin{array}{l}\text { Creative and innovative } \\
\text { Subjectivity }\end{array}$ & $0.306^{* *}$ & 0.004 & 74 \\
\hline 15 & $\begin{array}{l}\text { Frequent informal top-down and bottom-up } \\
\text { communications. }\end{array}$ & $0.410^{* *}$ & 0.000 & 75 \\
\hline 16 & Cross-functional teams. & $0.405^{* *}$ & 0.000 & 73 \\
\hline 17 & $\begin{array}{l}\text { Common understanding and interpretation of } \\
\text { knowledge }\end{array}$ & $0.384 * *$ & 0.000 & 74 \\
\hline 18 & $\begin{array}{l}\text { Transferability } \\
\text { Working closely with other related } \\
\text { departments/units }\end{array}$ & $0.369^{* *}$ & 0.001 & 75 \\
\hline 19 & Internal benchmarking & $0.543 * *$ & 0.000 & 74 \\
\hline 20 & Adapt knowledge from other applications & 0.166 & 0.080 & 73 \\
\hline
\end{tabular}

**Correlation is significant at the 0.01 level (1-tailed).

*Correlation is significant at the 0.05 level (1-tailed).

To test $\mathrm{H}_{5}$, Pearson's correlation coefficients are computed between each element of knowledge culture and each of Knowledge Management tasks of knowledge application, distribution, and cultivation. The result is presented in Table 6. 
Suitable knowledge culture should exist for sustaining success of knowledge management activities. It is noted in Table 6 that all the four existing knowledge culture elements are positively correlated with each of existing knowledge application, distribution, and cultivation tasks. All the coefficients are moderately high. The correlation coefficients are lowest for the knowledge cultivation task (last two columns of the Table 6 compared to knowledge application and distribution. It is concluded that the data support the hypothesis.

Table 6. Correlations between elements of knowledge culture and knowledge management tasks of knowledge application, distribution, and cultivation

\begin{tabular}{|c|c|c|c|c|c|c|}
\hline \multirow[b]{2}{*}{ Knowledge Culture } & \multicolumn{2}{|c|}{ Knowledge Application } & \multicolumn{2}{|c|}{ Knowledge Distribution } & \multicolumn{2}{|c|}{ Knowledge Cultivation } \\
\hline & $\begin{array}{l}\text { Pearson } \\
\text { Correlation }\end{array}$ & $\begin{array}{l}\text { Sig. } \\
\text { (1-tailed) }\end{array}$ & $\begin{array}{l}\text { Pearson } \\
\text { Correlation }\end{array}$ & $\begin{array}{l}\text { Sig. } \\
\text { (1-tailed) }\end{array}$ & $\begin{array}{l}\text { Pearson } \\
\text { Correlation }\end{array}$ & $\begin{array}{l}\text { Sig. } \\
\text { (1-tailed) }\end{array}$ \\
\hline $\begin{array}{l}\text { Recognize and } \\
\text { praise for creative } \\
\text { ideas }\end{array}$ & $0.394 * *$ & $\begin{array}{l}0.000 \\
(\mathrm{~N}=75)\end{array}$ & $0.438^{* *}$ & $\begin{array}{l}0.000 \\
(\mathrm{~N}=75)\end{array}$ & $0.345^{* *}$ & $\begin{array}{l}0.001 \\
(\mathrm{~N}=75)\end{array}$ \\
\hline $\begin{array}{l}\text { Support by top } \\
\text { management }\end{array}$ & $0.396^{* *}$ & $\begin{array}{l}0.000 \\
(\mathrm{~N}=75)\end{array}$ & $0.343^{* *}$ & $\begin{array}{l}0.001 \\
(\mathrm{~N}=75)\end{array}$ & $0.333 * *$ & $\begin{array}{l}0.002 \\
(\mathrm{~N}=75)\end{array}$ \\
\hline $\begin{array}{l}\text { Employees actively } \\
\text { involved in } \\
\text { improvement } \\
\text { decisions }\end{array}$ & $0.357^{* *}$ & $\begin{array}{l}0.001 \\
(\mathrm{~N}=75)\end{array}$ & $0.359 * *$ & $\begin{array}{l}0.001 \\
(\mathrm{~N}=75)\end{array}$ & $0.280^{* *}$ & $\begin{array}{l}0.007 \\
(\mathrm{~N}=75)\end{array}$ \\
\hline $\begin{array}{l}\text { Increase emphasis } \\
\text { on human aspects } \\
\text { in the performance } \\
\text { appraisals }\end{array}$ & $0.244^{*}$ & $\begin{array}{l}0.018 \\
(\mathrm{~N}=74)\end{array}$ & $0.211^{*}$ & $\begin{array}{l}0.036 \\
(\mathrm{~N}=74)\end{array}$ & $0.197^{*}$ & $\begin{array}{l}0.047 \\
(\mathrm{~N}=74)\end{array}$ \\
\hline
\end{tabular}

\section{Summary and Conclusion}

The present paper investigates the Knowledge Management (KM) practices in an electricity distribution company in Malaysia (known as TNBD), how the managers in the organization perceive the importance of KM, the difficulty to carry out KM practices in the organization, and the impact of the knowledge-oriented behaviour/activities on the organization performance. The paper focuses on the human aspects of KM rather than the IT aspects. The paper focuses on twenty knowledge-oriented activities (categorized into seven categories) and three knowledge tasks (knowledge application, distribution, cultivation).

Following are the main findings of the paper:

1) Managers prefer that knowledge cultivation, distribution and use to be part of their practice. They perceived that knowledge application, distribution and cultivation tasks are important to TNBD.

All the KM tasks (knowledge application, knowledge distribution, and knowledge cultivation) are perceived as importance to the organization. Knowledge cultivation is the most important, followed by knowledge distribution and knowledge application. TNBD has always been applying their knowledge in activities such as in the electricity supply project implementation and maintenance work, but knowledge sharing is needed most for increasing organization performance, to be supported by ingenuity and creativity (elements of knowledge cultivation) of the employees to complement the task of knowledge application.

2) The existing practices in the three tasks of knowledge application, distribution, and cultivation (they are also collectively known as knowledge management process or cycle) are positively correlated with the ease of occurrence of knowledge-oriented activities that support those tasks.

In existing practice, knowledge application ranks the highest average value of responses, followed by knowledge 
cultivation and knowledge distribution. The managers perceived that the task of knowledge cultivation is the most difficult task, distribution is less difficult, and knowledge application is the least difficult to do. This is because TNBD's employees, by virtue of their functions, especially technical functions, are trained and be equipped with technical skills and knowledge. They find that applying knowledge is least difficult compared to distributing or cultivating knowledge.

3) There are positive correlations between human behaviour and the ease with which the knowledge activities can occur.

For some activities, the behaviour aspects are positively correlated with the ease with which knowledge activities can occur. These activities are in the five categories of "Culture", "Embeddedness", "Spontaneity", "Subjectivity", and "Transferability".

4) The behaviour aspects are explained more by the perceived importance of the knowledge activities than the ease with which the activities can occur.

This conclusion is true for the five categories of knowledge activities of "Perishability", "Self-reinforcement", "Spontaneity", "Subjectivity", and "Transferability".

5) The human side of knowledge management oriented behaviour is correlated with the organization performance.

6) There are positive correlations between existing knowledge management tasks with each of the knowledge culture elements of the knowledge activities.

The positive correlations between each of culture elements and each of knowledge application, distribution, and cultivation tasks mean that support by top management, recognition and rewards for creative ideas, active participation of employees in decision-making, and performance appraisals that reflects human aspects are important motivators for successful KM.

\section{References}

Bennett, R., \& Gabriel, H. (1999). Organizational Factors and Knowledge Management within Large Marketing Departments: An Empirical Study. Journal of Management, 3(3), 212-215.

Brooking, A. (1999). Corporate Memory: Strategies for Knowledge Management. UK: International Thomson Business Press.

Costello, G. (1996). Knowledge Management in Strategic Alliances: the Role of Information Technology. Thesis (D.Phil), University of Oxford, UK.

Davenport, T. H. (1994). Saving IT's Soul: Human-Centered Information Management. Harvard Business Review, March-April 1994.

Davenport, T. H., \& Prusak, L. (1998). Working Knowledge: How Organizations Manage What They Know. Boston, MA: Harvard Business School Press.

Drucker, P. F. (1992, September-October). The New Society of Organizations. Harvard Business Review.

Drucker, P. F. (1993). Post-Capitalist Society. New York: HarperCollins.

Drucker, P. F. (2002, August). The Discipline of Innovation. The Innovative Enterprise.

Frappaolo, C. (2002). Knowledge Management. Oxford, UK: Capstone Publishing.

Gamble, P. R., \& Blackwell, J. (2001). Knowledge Management: A State of the Art Guide. London, UK: Kogan Page Limited.

Garavelli, A. C., Sebastiano, G., Gorgoglione, M., Coviello, A., Nebbia, P., Petruzzellis, S., Lollino, M., \& Sardone, G. (2003). Theme 2: How Motivating Knowledge Workers: Synthesis Report. European KM Forum. Retrieved May 15, 2003, from http://www.knowledgeboard.com

Hildreth, P. M. (2000). 'Going the Extra Half-Mile' - International Communities of Practice and the Role of Shared Artifacts. Thesis (D.Phil), University of York, UK.

Iivari, J., \& Linger. (1999). Knowledge Work as Collaborative Work: A Situated Activity Theory View. In: Proceedings of the $32^{\text {nd }}$ Hawaii International Conference on System Sciences, 1999.

Kazmier, L. J., \& Pohl, N. F. (1984). Basic Statistics for Business and Economics (2nd ed.). Singapore: McGraw-Hill Co.

Kluge, J., Stein, W., \& Licht, T. (2001). Knowledge Unplugged: The McKinsey \& Company Global Survey on 
Knowledge Management. New York: Palgrave. (Dr. Nikolai Dobberstein from McKinsey \& Company Malaysia summarized the materials from the book in his invited lecture at Institute of Global Management, 2001).

Merali, Y. (2001). Building and Developing Capabilities: A Cognitive Congruence Framework. In R. Sanchez (Ed.), Knowledge Management and Organizational Competence (pp. 41-62). Oxford: Oxford University Press.

Nonaka, I. (1991, November-December). The Knowledge-Creating Company. Harvard Business Review, 96-104.

Nonaka, I. (1994). A Dynamic Theory of Organizational Knowledge Creation. Organization Science, 5(1), 14-37. http://dx.doi.org/10.1287/orsc.5.1.14

Nonaka, I., \& Takeuchi, H. (1995). The Knowledge-Creating Company: How Japanese Companies Create the Dynamics of Innovation. New York: Oxford University Press.

O'Dell, C. S., Grayson, C. J., \& Essaides, N. (1998). If Only We Knew What We Know: The Transfer of Internal Knowledge and Best Practice. New York: The Free Press.

Pfeffer, J., \& Sutton, R. I. (2000). The Knowing-Doing Gap: How Smart Companies Turn Knowledge into Action. Boston, MA: Harvard Business School Press.

Raub, S. P. (2001). Towards a Knowledge-Based Framework of Competence Development. In R. Sanchez (Ed.), Knowledge Management and Organizational Competence (pp. 97-113). NY: Oxford University Press Inc., NY.

Sanchez, R. (2001). Managing Knowledge into Competence: The Five Learning Cycles of the Competent Organization. In R. Sanchez (Ed.), Knowledge Management and Organizational Competence (pp. 3-37). NY: Oxford University Press Inc., NY.

Sivula, P. (2001). Competence-Based Competition: Gaining Knowledge from Client Relationships. In R. Sanchez (Ed.), Knowledge Management and Organizational Competence (pp. 77-94). NY: Oxford University Press Inc., NY.

Tiwana, A. (2000). The Knowledge Management Toolkit: Practical Techniques for Building a Knowledge Management System. NJ: Prentice-Hall.

\section{Notes}

Note 1. p. xxii.

Note 2. p. 30 .

Note 3. The distinction between explicit knowledge (sometimes referred as formal or represented knowledge) and tacit knowledge (referred as informal or embodied knowledge) is first proposed by Michael Polanyi (Gamble \& Blackwell, 2001, p.11).

Note 4. Total numbers of employees within TNB Group are 23,573. Source: TNB.

Note 5 . Such as the minimum rate of electricity supply breakdowns, and project completion time.

Note 6. Such as the one used in Buckman Labs or BP Amoco.

Note 7. Exploitation of knowledge is the development of new generation of applications (different products, processes, and services) from current successes (Drucker, 1992, 1993).

Note 8. A lecture given by Nikolai Dobberstein, McKinsey \& Co. on February 3, 2002 at the Institute of Global Management, Malaysia.

\section{Copyrights}

Copyright for this article is retained by the author(s), with first publication rights granted to the journal.

This is an open-access article distributed under the terms and conditions of the Creative Commons Attribution license (http://creativecommons.org/licenses/by/3.0/). 